新入会入員 (昭和 44 年 12 月 30 日 眧和 45 年 1 月 27 日)

\section{維 持 員 大久保歯車工業株式会社}

正員

和田浩明東大工

木村希夫豊田中研

斎藤一男 金材技研

浜本道夫 不二越東富山慗銅所

西尾昭二 能本犬工

砂山寬之!

高見沢秀男 日本笔気中砸

小沢正俊 大同製鉿知多工場

喜多善史阪大工

長谷場泰造 神戸製鋼所中研

工藤 豊

小林郁夫

服部成雄

大西脩嗣

藤井則久

甲斐 幹

学生員

山形建男

長卻川隆三

戴錫勇 " 工

藪野良平大阪府大工

今沢 等 阪大工

黒田健三

島谷博之

井戸 敏

上田完次

木川 泓

多賀 豊

小原雅 信

片岡俊彦

小林茂樹
鈴木良一八䁖製鉄東研

河合 望 名大工

堀江宏道 東芝総合研

新谷与一郎 日本ステンレス直江津製造所

渋 谷敦 義 住友金属工業中砳

室谷幸成

瀬戸隆史

渡辺正次

溝口幸美

上田治

村井香一

笠井昌巳

飯田凡雄

本多文洋

大野勇一

新原晧一

中川止信

今里彰秀

橋本丈治

栗田康雄

岸田靖雄

由中皓 " 大学院

中里福和東大工

奥村直樹 "

杉浦勇夫 名工大金属

小豆島 明

飯田雅

大沢敏

石川明成

梅垣俊造
戸沢浩一

布施 紘

荒井泰治

大橋健二

山本勝 美 日本揮発油

山本力川崎炉材唎

河原勝 日本ナショナル金錢登鉒機

奥 達雄 日本原汧

高橋 修 日本工業試験所

福田悦 郎三菱製鋼技研

小杉 允 " 長崎製銅所

大西泰次郎 三菱金属䤠業中研

広瀬博一

小野田武司

岡本譲治 名工大金属

上舘良興

北㿟哲也

中村武美

西田建

星野秀弘

三浦健蔵

谷津孝芝浦工大

富樫英明東海大

松本良夫"

前川 清 美 金沢大工

石原寬二 能本大工

麻生智崇 九工大金属

川沢建夫愛媛大大学院

正誤表（第 8 卷 第 9 号揭載）

\begin{tabular}{|c|c|c|c|}
\hline 頁 & 段 & 㖞 & 正 \\
\hline 605 & $\begin{array}{l}\text { 右上加 } 12 \text { 行目 } \\
\text { (2) 式 }\end{array}$ & $\Delta F_{p}=4 / 3 \pi r^{3} \Delta F_{v}+4 \pi r^{2} \sigma+4 / 3 \pi r^{2} \varepsilon$ & $\Delta F_{p}=4 / 3 \pi r^{3} \Delta F_{v}+4 \pi r^{2} \sigma+4 / 3 \pi r^{3} \varepsilon$ \\
\hline
\end{tabular}

\section{編}

集

$\diamond$ 本号は北陸信越地区の森棟隆弘理事に企画と編集を 特放がいいたしました，森棟理事の招骨折りを感謝申 し上げます。また，ご多忙のなかをご執筆下さいまし た小田仲彬, 井戸原 満, 近藤正男, 成瀬 亘, 前波 力, 池野尚志, 松野純一, 室町繁雄, 多々静夫の各氏 に厚く御礼申し上げます。

$\diamond$ 本年度特集号のテーマが「溶融金属溶液」と「金属 製錬の化学」に決まり，ただいまそれぞれ担当委員の もとで準備が進められて物ります。ご期待下さい。

$\diamond$ 今年の春の大会は学校の使用が困難となり, 三つの ビルにわかれて開かれることになりました。それぞれ の会場がはなれておりりまをた会場の設備もまちまちで 参加各位には何かと不便を扔かけいたしますが，事情

\section{後 記}

をご理解下さいまして，何とぞご協力下さいますよう 抒ねがいいたします。

$\diamond$ 出講者の方々には，その準備仍かられていること と思いますが，講演会で使用されるスライドが不鮮明 だったり，図表の文字が小さく，見にくかったりで は，折角の講演もその成果を十分にあげることができ ません，こ机らの作成にはとくに配慮されるよら拈视 がいいたします。

$\diamond 2$ 月投稿の研究論文は 34 巻 7 8 号辺溌表の予定 ですが，論文そのものに問題がなければ揭載の時期は いまのところ, さらに早まる見込です。ふるるってご投 稿下さい。 